\title{
Pd/ZnO catalysts with different origins for high chemoselectivity in acetylene semi-hydrogenation
}

\author{
Huiran Zhou a,b, Xiaofeng Yang a,*, Aiqin Wang a,\#, Shu Miao a, Xiaoyan Liu a, Xiaoli Pan a, Yang Su a, \\ Lin Li a, Yuan Tan a, Tao Zhang a \\ a State Key Laboratory of Catalysis, iChEM (Collaborative Innovation Center of Chemistry for Energy Materials), Dalian Institute of Chemical Physics, \\ Chinese Academy of Sciences, Dalian 116023, Liaoning, China \\ b University of Chinese Academy of Sciences, Beijing 100049, China
}

\section{A R T I C L E I N F O}

Article history:

Received 26 February 2016

Accepted 28 March 2016

Published 5 May 2016

\section{Keywords:}

Single atom catalyst

Acetylene semi-hydrogenation

Chemoselectivity

Palladium

Zinc oxide

\begin{abstract}
A B S T R A C T
The heterogeneity of active sites is the main obstacle for selectivity control in heterogeneous catalysis. Single atom catalysts (SACs) with homogeneous isolated active sites are highly desired in chemoselective transformations. In this work, a $\mathrm{Pd}_{1} / \mathrm{ZnO}$ catalyst with single-atom dispersion of $\mathrm{Pd}$ active sites was achieved by decreasing the Pd loading and reducing the sample at a relatively low temperature. The $\mathrm{Pd}_{1} / \mathrm{ZnO}$ SAC exhibited excellent catalytic performance in the chemoselective hydrogenation of acetylene with comparable chemoselectivity to that of PdZn intermetallic catalysts and a greatly enhanced utilization of Pd metal. Such unusual behaviors of the $\mathrm{Pd}_{1} / \mathrm{ZnO}$ SAC in acetylene semi-hydrogenation were ascribed to the high-valent single Pd active sites, which could promote electrostatic interactions with acetylene but restrain undesired ethylene hydrogenation via the spatial restrictions of $\sigma$-chemical bonding toward ethylene.
\end{abstract}

(C) 2016, Dalian Institute of Chemical Physics, Chinese Academy of Sciences. Published by Elsevier B.V. All rights reserved.

\section{Introduction}

Chemoselectivity is one of the most important factors for evaluating the economic benefit of catalytic industries because of its direct relation to the value of products as well as the final separation costs in the heterogeneous processes [1,2]. Two aspects of surface features govern the selectivity profile of a chemoselective transformation with heterogeneous materials as catalysts. First, supported catalysts are generally composed of a spectrum of distribution of metal nanoparticles that consists of several to thousands of metal-atom ensembles. Each of these ensembles has its own energetically favored chemoselective product, which therefore leads to a correspondingly broad spectrum of products [1]. Second, even for each multi-metal ensembles, it can provide non-exclusive pathways for the adsorption and evolution of starting reactants [1,3-5], which poses a great challenge in chemoselective control in the heterogeneous catalytic processes. As a result, it is highly desired to develop new catalysts with not only homogeneous size, but also atomically distributed metal active sites for chemoselective transformations.

In our previous research [6], we have achieved homogeneous distribution of Pd active sites within unique Pd-Zn-Pd ensembles by intermetallic alloying of Pd with $\mathrm{Zn}$ on $\mathrm{Pd} / \mathrm{ZnO}$ catalysts during reduction at $400{ }^{\circ} \mathrm{C}$. Such $\mathrm{PdZn}$ intermetallic nanostructures are both highly active and selective for the

\footnotetext{
* Corresponding author. Tel: +86-411-84379416; Fax: +86-411-84685940; E-mail: yangxf2003@dicp.ac.cn

\# Corresponding author. Tel: +86-411-84379348; Fax: +86-411-84685940; E-mail: aqwang@dicp.ac.cn

This work was supported by the National Natural Science Foundation of China (21573232).

DOI: 10.1016/S1872-2067(15)61090-7 | http://www.sciencedirect.com/science/journal/18722067 | Chin. J. Catal., Vol. 37, No. 5, May 2016
} 
semi-hydrogenation of acetylene to ethylene, which is usually inaccessible because the hydrogenation of acetylene generally proceeds via a thermodynamically favored, sequential hydrogenation to the undesired ethane $\left(\mathrm{C}_{2} \mathrm{H}_{2} \rightarrow \mathrm{C}_{2} \mathrm{H}_{4} \rightarrow \mathrm{C}_{2} \mathrm{H}_{6}\right)$, especially at high conversions of acetylene, but which must be reduced to ppm level in ethylene feedstock to avoid poisoning Ziegler-Natta polymerization catalysts [7-12]. The appropriate spatial arrangement of Pd active sites in the Pd-Zn-Pd ensembles of PdZn alloys is found to lead a $\sigma$-bonding mode of acetylene with two neighboring $\mathrm{Pd}$ sites and a weak $\pi$-bonding pattern toward ethylene adsorption on the single Pd site, which facilitates acetylene chemisorption and promotes the desorption of ethylene from the catalyst surface. This results in kinetic favoring of the selective conversion of acetylene to ethylene [6]. Accordingly, another possible method for high chemoselectivity in acetylene semi-hydrogenation would be isolating Pd active sites with solid supports to form supported single atom catalysts (SACs), which provide not only homogeneous metal active sites, but also maximum utilization of metal atoms and unique active site oxidation states. Such SACs have also been reported to exhibit excellent activity and selectivity in a variety of catalytic processes [13-17]. For example, we have previously reported that the single atom or the pseudo-single-atom $\mathrm{Pt}$ catalyst supported on $\mathrm{FeO}_{x}$ exhibits $99 \%$ selectivity in the hydrogenation of 3-nitrostyrene to 3-aminostyrene with a turn-over frequency as high as $1500 \mathrm{~h}^{-1}$ due to the distinct adsorption of nitro group and $\mathrm{C}=\mathrm{C}$ bond over positively charged single platinum centers [17]. Hence, this new type of SAC provides an excellent opportunity for designing new catalysts for chemoselective transformations.

Herein, single Pd active sites were achieved by decreasing the metal loading on the $\mathrm{ZnO}$ support. Our characterization results indicate that the $\mathrm{Pd}$ nanoparticle size decreases when decreasing the Pd loading from $1 \%$ to $0.1 \%$, and becomes isolated single atom $\mathrm{Pd}$ sites on the $0.01 \% \mathrm{Pd} / \mathrm{ZnO}$ sample. Unexpectedly, this $\mathrm{Pd}_{1} / \mathrm{ZnO} \mathrm{SAC}$ exhibits excellent catalytic performance in the chemoselective hydrogenation of acetylene, with comparable chemoselectivity and an improved activity compared with that of our previously reported PdZn intermetallic catalysts, which was ascribed to the high-valent single Pd active sites on the $\mathrm{ZnO}$ support.

\section{Experimental}

\subsection{Catalyst synthesis}

Different $\mathrm{Pd} / \mathrm{ZnO}$ catalysts, with nominal metal loadings of $1 \mathrm{wt} \%, 0.1 \mathrm{wt} \%$, and $0.01 \mathrm{wt} \%$, were synthesized by incipient wet impregnation of $\mathrm{ZnO}$ (BET surface area of $2.9 \mathrm{~m}^{2} / \mathrm{g}$ ) with a prediluted solution of palladium nitrate. Prior to impregnation, the support was dried at $120^{\circ} \mathrm{C}$ for $8 \mathrm{~h}$. After impregnation at ambient temperature, the samples were dried at $120^{\circ} \mathrm{C}$ for 12 $\mathrm{h}$ and then calcined at $400{ }^{\circ} \mathrm{C}$ for $3 \mathrm{~h}$ at a heating rate of 2 ${ }^{\circ} \mathrm{C} / \mathrm{min}$.

\subsection{Catalyst characterization}

The temperature-programmed reduction (TPR) was carried out on a Micromeritic AUTOCHEM II 2920. For the $\mathrm{H}_{2}$-TPR experiment, the catalyst $(0.26,0.26$ and $0.55 \mathrm{mg}$ for $1 \%, 0.1 \%$ and $0.01 \%-\mathrm{Pd} / \mathrm{ZnO}$, respectively) was placed in a U-shaped quartz reactor and pretreated at $200{ }^{\circ} \mathrm{C}$ for $1 \mathrm{~h}$ under an $\mathrm{Ar}$ flow to remove adsorbed carbonates and hydrates. As the PdO species may be readily reduced even below room temperature, the sample was cooled to $-50{ }^{\circ} \mathrm{C}$ by a cold trap, and the experiment was performed under $10 \mathrm{Vol} \% \mathrm{H}_{2} / \mathrm{Ar}$ from -50 to $600{ }^{\circ} \mathrm{C}$ under a ramping rate of $10{ }^{\circ} \mathrm{C} / \mathrm{min}$. The consumption of $\mathrm{H}_{2}$ was monitored with a thermal conductivity detector (TCD).

X-ray diffraction (XRD) patterns were recorded using a PW3040/60 X'Pert PRO (PANalytical) diffractometer with a copper anode ( $\mathrm{Cu} K_{\alpha}, \lambda=0.15432 \mathrm{~nm}$ ), operating at $40 \mathrm{kV}$ and $40 \mathrm{~mA}$ and a scanning angel $(2 \theta)$ of $10^{\circ}-80^{\circ}$.

A JEOL JEM-2100F microscope equipped with scanning transmission electron microscopy (STEM) and Oxford detectors was employed to acquire the transmission electron microscopy (TEM) and STEM images and the energy-dispersive X-ray spectral (EDS) data at $200 \mathrm{kV}$. To obtain the Pd particle size distribution, a few hundred Pd particles (160-250) from different areas were counted. For $0.01 \%-\mathrm{Pd} / \mathrm{ZnO}$, subångström-resolution high-angle annular dark-field scanning transmission electron microscopy (HAADF-STEM) characterization was also carried out on a JEOL JEM-ARM200F STEM/TEM equipped with a CEOS probe corrector, with a guaranteed resolution of $0.08 \mathrm{~nm}$. The samples were suspended in ethanol with an ultrasonic dispersion of $15 \mathrm{~min}$, and then two drops of the resulting solution were dropped onto a copper grid and dried at room temperature for electronic imaging.

X-ray absorption spectra (XAS), including X-ray absorption near-edge structure (XANES) and extended X-ray absorption fine structure (EXAFS) at the Pd K-edge, were recorded at the BL14W1 at the Shanghai Synchrotron Radiation Facility, Shanghai Institute of Applied Physics, China. A double Si(311)-crystal monochromator was used for energy selection. The energy was calibrated by $\mathrm{Pd}$ foil. Before the experiments, all the samples were reduced at $100{ }^{\circ} \mathrm{C}$ and were sealed with Kapton films in the glove box. The spectra were collected at room temperature under fluorescence mode with a solid state detector. The data were analyzed using the Athena software package. The ranges used for data fitting in $\kappa$-space and $R$-space were $\Delta \kappa: 3.0-12.9 \AA^{-1}$ and $\Delta R: 1.2-2.9 \AA$, respectively.

In situ X-ray photoelectron spectroscopy (XPS) measurements were performed on a Thermo ESCALAB 250Xi spectrometer employing a monochromatic Al X-ray source $\left(\mathrm{Al} K_{\alpha}=\right.$ $1846.6 \mathrm{eV}$ ), operated at $15 \mathrm{kV}$ and $10.8 \mathrm{~mA}$. The samples were ground and pressed to circular pellets of $\sim 1 \mathrm{~mm}$ thickness using a stainless steel pressing tool and then mounted on a sample holder. The samples were reduced in situ in hydrogen at 100 or $400{ }^{\circ} \mathrm{C}$. The spectra were subsequently collected using an analyzer pass energy of $50 \mathrm{eV}$ at room temperature. The base and operating pressure were $1 \times 10^{-8} \mathrm{~Pa}$ and $7.1 \times$ $10^{-5} / 7.1 \times 10^{-7} \mathrm{~Pa}$. XPSPEAK software was used for qualitative and quantitative analyses of the XPS data. The $\mathrm{C} 1 s$ peak of adventitious $\mathrm{C}$ at $284.6 \mathrm{eV}$ was used for energy calibration. The collected spectra were fit by a least squares routine using 
Gaussian and Lorentzian lines after background subtraction. The surface concentration of each element was calculated as follows [18]:

$$
\frac{n_{1}}{n_{2}}=\frac{I_{1}}{I_{2}} \times \frac{\sigma_{2}}{\sigma_{1}} \times \frac{E_{k_{2}}{ }^{0.5}}{E_{k_{1}}^{0.5}}
$$

where $n, I, \sigma$, and $E_{k}$ (subscript of 1,2 represent corresponding element) in the formula represent the count of each atom on the surface, the intensity (area) of the corresponding peak, the photoionization cross-section of the corresponding energy level of the corresponding peak, and the kinetic energy of the emitted electron, respectively.

\subsection{Catalyst testing}

The semi-hydrogenation of acetylene in the excess ethylene over these three catalysts was evaluated in a continuous flow fixed-bed reactor, described elsewhere [6]. A quartz tube with an inner diameter of $4 \mathrm{~mm}$ was used as the reactor. Prior to reaction, the $\mathrm{Pd} / \mathrm{ZnO}$ catalysts diluted with quartz sand were reduced in situ at $100{ }^{\circ} \mathrm{C}$ with pure hydrogen for $1 \mathrm{~h}$, followed by cooling to $80{ }^{\circ} \mathrm{C}$ for performance testing. The reaction gas contained $2 \mathrm{Vol} \% \mathrm{C}_{2} \mathrm{H}_{2}, 20 \mathrm{Vol}_{\%} \mathrm{H}_{2}, 40 \mathrm{Vol}_{\%} \mathrm{C}_{2} \mathrm{H}_{4}$, and $\mathrm{He}$ as a balance gas with a total flow rate of $30 \mathrm{~mL} / \mathrm{min}$. The main challenge in acetylene hydrogenation is the general difficulty in attaining high selectivity toward ethylene because of the sequential hydrogenation of ethylene at high conversion of acetylene. Because of this, as well as for a distinct comparison of the catalytic performances of different catalysts, the optimized amount of these three catalysts (3.8 mg 1\%-Pd/ZnO, $9.0 \mathrm{mg}$ $0.1 \%-\mathrm{Pd} / \mathrm{ZnO}$, and $50.0 \mathrm{mg} 0.01 \%-\mathrm{Pd} / \mathrm{ZnO}$ ) were used to keep a high stable conversion rate $(>80 \%)$ but under the complete conversion of acetylene. The gas composition at the inlet and outlet were analyzed using an online Agilent Technologies $6890 \mathrm{~N}$ gas chromatograph with a flame ionization detector (FID) and a PORAPAK-N column. A small amount of "green oil" was found to be deposited on the outlet of the reaction tube after reaction, while $\mathrm{C} 2$ species are the predominant products according to our previous product analysis [6]. To clarify the catalytic mechanism of $\mathrm{C}=\mathrm{C}$ and $\mathrm{C} \equiv \mathrm{C}$ hydrogenation on our $\mathrm{Pd} / \mathrm{ZnO}$ catalyst, the ethylene selectivity in the $\mathrm{C} 2$ products was present in the text. Conversion $(C)$ and selectivity $(S)$ were calculated as follows $[19,20]$ :

$$
\begin{gathered}
C=\frac{\mathrm{C}_{2} \mathrm{H}_{2} \text { (in) }-\mathrm{C}_{2} \mathrm{H}_{2} \text { (out) }}{\mathrm{C}_{2} \mathrm{H}_{2} \text { (in) }} \times 100 \% \\
S=\left(1-\frac{\mathrm{C}_{2} \mathrm{H}_{6} \text { (out) }-\mathrm{C}_{2} \mathrm{H}_{6} \text { (in) }}{\mathrm{C}_{2} \mathrm{H}_{2} \text { (in) }-\mathrm{C}_{2} \mathrm{H}_{2} \text { (out) }}\right) \times 100 \%
\end{gathered}
$$

where $\mathrm{C}_{2} \mathrm{H}_{x}$ (in) and $\mathrm{C}_{2} \mathrm{H}_{x}$ (out) $(x=2,4,6)$ in the formulas represent the concentrations of the corresponding gas analyzed by chromatograph before or after reaction, respectively.

\section{Results and discussion}

\subsection{Catalytic characterization}

To obtain differently sized Pd species on the support, $\mathrm{Pd} / \mathrm{ZnO}$ catalysts with nominal metal loadings of $1 \mathrm{wt} \%, 0.1$ wt $\%$, and 0.01 wt $\%$ were synthesized. Fig. 1 shows the $\mathrm{H}_{2}$-TPR profiles for these three catalysts. As the PdO species can be readily reduced to metal phase even below room temperature, the TPR experiments were conducted from temperatures as low as -50 up to $600{ }^{\circ} \mathrm{C}$. Both the $1 \%$ and $0.1 \%-\mathrm{Pd} / \mathrm{ZnO}$ catalysts display distinct peaks at relatively low temperatures (from -30 to $100{ }^{\circ} \mathrm{C}$ ). By quantification, the actual hydrogen consumption on these two catalysts is much higher than the theoretical values for a stoichiometric reduction of a PdO to the Pd species. This can be ascribed to the formation of a palladium hydride phase or the hydrogen spillover from Pd to the surface of the $\mathrm{ZnO}$ support [21-23]. Meanwhile, a broad peak from 100 to $500{ }^{\circ} \mathrm{C}$ was observed for these two catalysts, which is related to partial reduction of $\mathrm{ZnO}$ in the formation of the PdZn intermetallic phase [21-24]. It indicates that the formation of the PdZn intermetallic alloy occurs only at a relatively high temperature $\left(>100{ }^{\circ} \mathrm{C}\right)$, and behaves as a much slower process [25]. No hydrogen consumption peak was observed for the $0.01 \%-\mathrm{Pd} / \mathrm{ZnO}$ sample during the entire experiment because of the low Pd loading. As the PdZn intermetallic catalyst has already been proven effective for acetylene semi-hydrogenation in our previous work [6] as well as other reports [26,27], the final $\mathrm{Pd} / \mathrm{ZnO}$ catalysts in this work were obtained and tested at a relatively low reduction temperature $\left(100{ }^{\circ} \mathrm{C}\right)$ to avoid the formation of intermetallic catalyst.

The XRD patterns of $1 \%-\mathrm{Pd} / \mathrm{ZnO}$ and $0.1 \%-\mathrm{Pd} / \mathrm{ZnO}$ catalysts after reduction at $100^{\circ} \mathrm{C}$ are displayed in Fig. 2. Other than the distinct reflection peaks of the wurtzite-type phase of $\mathrm{ZnO}$, no other diffraction peaks were detected, indicating the strong metal-support interactions between $\mathrm{Pd}$ and $\mathrm{ZnO}$ with the $\mathrm{Pd}$ species well-distributed on the ZnO support. Correspondingly, as indicated in the representative TEM images and particle size distributions in Fig. 3, the 1\% and 0.1\%-Pd/ZnO Pd nanoparticles display a hemispherical morphology on the support. Based on statistical analysis of $\sim 200$ nanoparticles, the metal particle size of the $1 \%-\mathrm{Pd} / \mathrm{ZnO}$ sample ranges from 1.5 to $9 \mathrm{~nm}$ with a

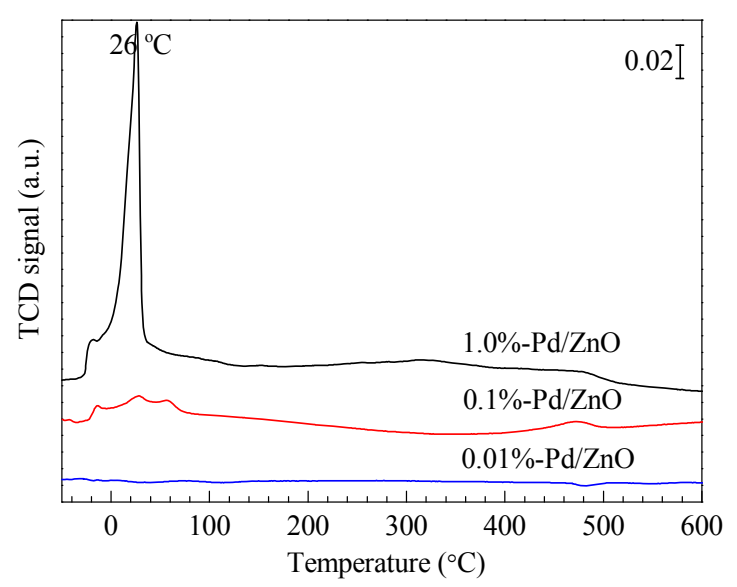

Fig. 1. TPR profiles of different $\mathrm{Pd} / \mathrm{ZnO}$ catalysts. Experiments were performed from $-50{ }^{\circ} \mathrm{C}$ in $10 \% \mathrm{H}_{2} / \mathrm{Ar}$ flow with a heating rate of 10 ${ }^{\circ} \mathrm{C} / \mathrm{min}$. 


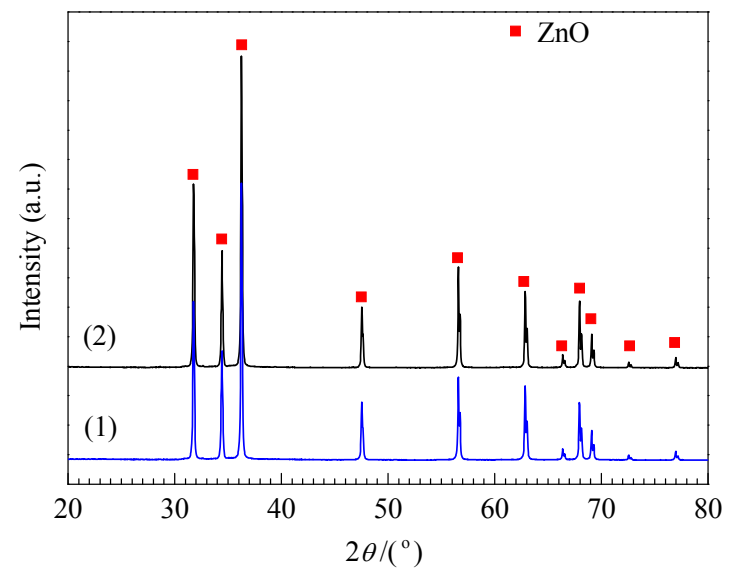

Fig. 2. XRD patterns of $1 \%-\mathrm{Pd} / \mathrm{ZnO}(1)$ and $0.1 \%-\mathrm{Pd} / \mathrm{ZnO}(2)$ after reduction at $100^{\circ} \mathrm{C}$.

mean size of $3.8 \mathrm{~nm}$, while it ranges from 0.3 to $2.8 \mathrm{~nm}$ with an average size of $0.9 \mathrm{~nm}$ for the $0.1 \%-\mathrm{Pd} / \mathrm{ZnO}$ catalyst. When further decreasing the Pd loading to $0.01 \%$, no particles can be distinguished in our TEM images. To determine whether Pd was present in a random sample zone, STEM equipped with EDS analysis was also performed for this sample. As we can see in Figs. 3(d) and (e), while the EDS signal of Pd species is relatively weak due to the low Pd loading, it can still serve as qualitative evidence for the presence of palladium on this $0.01 \%-\mathrm{Pd} / \mathrm{ZnO}$ catalyst, in which the Pd species might be isolated on the $\mathrm{ZnO}$ support. Fortunately, by carefully analyzing the sample with HAADF-STEM equipped with a CEOS probe corrector (Fig. 3(f)), an exclusive single-atom distribution of Pd sites was observed on the support. Hence, decreasing Pd loading on the $\mathrm{ZnO}$ support leads to smaller Pd nanoparticles, and single Pd atoms on the support as the Pd loading decreases to $0.01 \%$, which serves as a single atom catalyst and is denoted as $\mathrm{Pd}_{1} / \mathrm{ZnO} \mathrm{SAC}$ in this report.

To obtain the oxidation state as well as the coordination environment of $\mathrm{Pd}$ active sites, XAS measurements were performed on our $\mathrm{Pd} / \mathrm{ZnO}$ catalysts at the K-edge of Pd after reduction at $100{ }^{\circ} \mathrm{C}$. The $0.01 \%-\mathrm{Pd} / \mathrm{ZnO}$ sample was not considered here because of its comparatively low Pd content. From the XANES spectra shown in Fig. 4(a), the $1 \%$ and $0.1 \%$-Pd/ZnO samples exhibit an absorption edge at approximately $24350 \mathrm{eV}$, with near-edge peaks centered at $\sim 24367$, 24389 , and $24428 \mathrm{eV}$, respectively, akin to those of Pd foil, indicating that the $\mathrm{Pd}$ atoms are in a predominantly metallic state [28]. However, as seen in Fig. 4(b), there are also some deviations in the $\kappa$-space of the EXAFS spectra between the Pd/ZnO samples and the Pd foil, suggesting that the other coordination shells also make some contributions to its coordination environment. The Fourier transforms of $\kappa^{3}$-weighted EXAFS spectra are shown in Fig. 4(c), with the fitting results summarized in Table 1. The best fitted coordination parameters for $1 \%-\mathrm{Pd} / \mathrm{ZnO}$ are Pd-Pd neighbors with a coordination number of 5.1, accompanied by some contributions from $\mathrm{Pd}-\mathrm{Zn}$ and Pd-O shells. When decreasing the loading to $0.1 \%$, the coordination number of $\mathrm{Pd}-\mathrm{Pd}$ neighbors decreases to 4.2, suggesting the smaller size of $\mathrm{Pd}$ in the $0.1 \%-\mathrm{Pd} / \mathrm{ZnO}$ catalyst [29] in agreement with the TEM results. Meanwhile, the coordination number of Pd-Zn slightly decreases but that of the Pd-O shell increases, indicating that the Pd species becomes more difficult to reduce and more positive as the loading of Pd decreases.

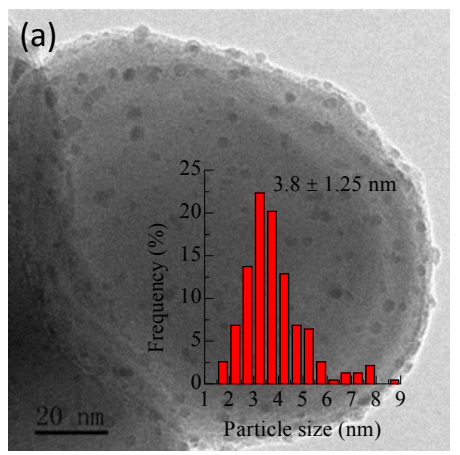

(b)
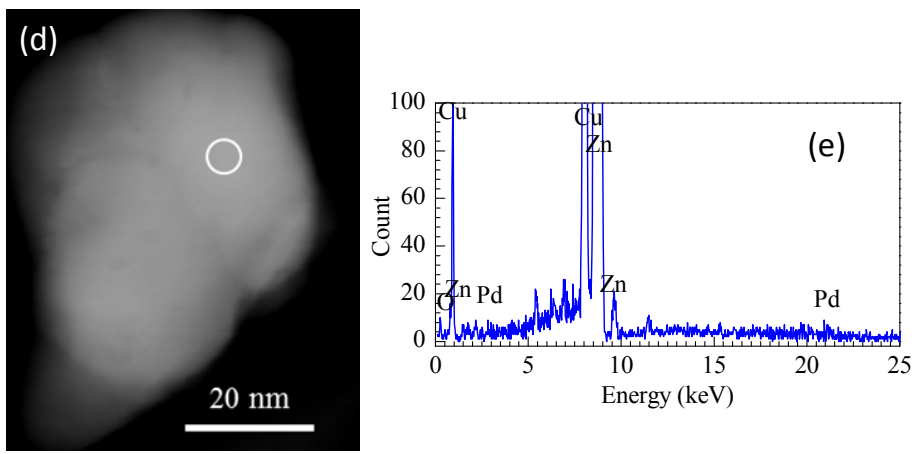

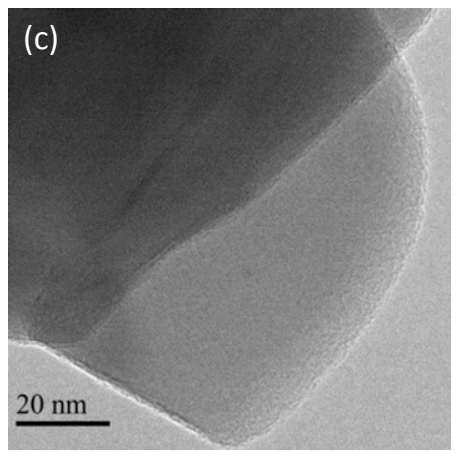

(f)

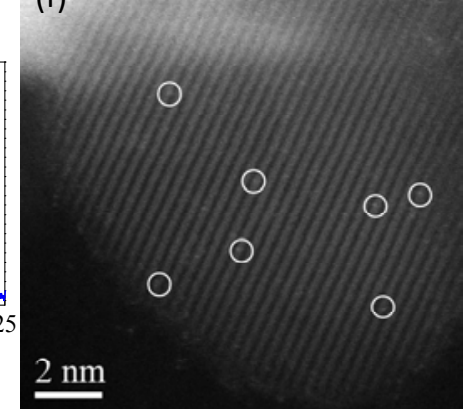

Fig. 3. TEM images and the corresponding particle size distributions of $1 \%-\mathrm{Pd} / \mathrm{ZnO}(\mathrm{a}), 0.1 \%-\mathrm{Pd} / \mathrm{ZnO}(\mathrm{b})$, and $0.01 \%-\mathrm{Pd} / \mathrm{ZnO}(\mathrm{c})$ reduced at $100{ }^{\circ} \mathrm{C}$; STEM (d) with energy dispersive X-ray spectrum (e) and HAADF-STEM image (f) for $0.01 \%$-Pd/ZnO reduced at $100{ }^{\circ} \mathrm{C}$. 

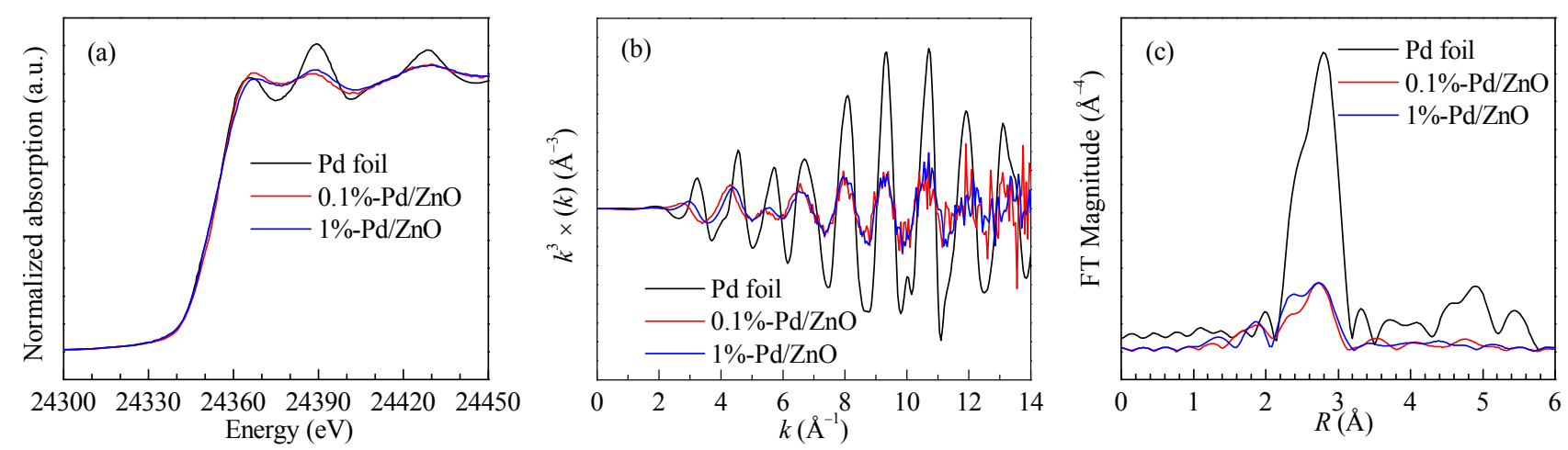

Fig. 4. The normalized XANES spectra at Pd K-edge (a), the $\kappa$-space EXAFS spectra (b), and the corresponding Fourier transform of $\kappa^{3}$-weighted EXAFS spectra (c) for Pd foil and Pd/ZnO catalysts with different loadings of Pd reduced at $100{ }^{\circ} \mathrm{C}$.

Fig. 5 illustrates the XPS spectra of Pd $3 d$ of the Pd/ZnO catalysts after in situ reduction at $100^{\circ} \mathrm{C}$, with the $1 \%-\mathrm{Pd} / \mathrm{ZnO}$ sample reduced at $400^{\circ} \mathrm{C}$ as a comparison. By deconvolving the spectral profiles, the corresponding binding energy as well as the $\mathrm{Pd}(0) / \mathrm{Pd}(+)$ ratio are determined (summarized in Table 2). As indicated in our XAS results, three distinct Pd oxidation states can be resolved for the $1 \%-\mathrm{Pd} / \mathrm{ZnO}$ catalyst after reduction at $100^{\circ} \mathrm{C}$, including the Pd component with a binding energy at $335.0 \mathrm{eV}$, which serves as a typical metallic Pd species $(\operatorname{Pd}(0))[22,30,31]$, the PdZn intermetallic phase with a binding energy at $335.4 \mathrm{eV}$ [32], as well as one with a binding energy at $336.0 \mathrm{eV}$ ascribed to oxidized palladium (PdO) [30]. In contrast, the $1 \%-\mathrm{Pd} / \mathrm{ZnO}$ sample reduced at $400{ }^{\circ} \mathrm{C}$ results in only a single peak at $335.6 \mathrm{eV}$, with a positive shift of binding energy ( 0.6 $\mathrm{eV})$ compared with that of the $\mathrm{Pd}(0)$ species from nanoparticles, which is ascribed to the PdZn intermetallic alloy $[22,33]$. Similar to the $1 \%-\mathrm{Pd} / \mathrm{ZnO}$ catalyst after reduction at $100^{\circ} \mathrm{C}$, the spectra recorded for the $0.1 \%-\mathrm{Pd} / \mathrm{ZnO}$ and $0.01 \%-\mathrm{Pd} / \mathrm{ZnO}$ samples also contain both the $\operatorname{Pd}(0)$ and $\operatorname{Pd}(+)$ components, however, the corresponding binding energy increases slightly while the ratio of $\operatorname{Pd}(0) / \mathrm{Pd}(+)$ decreases as decreasing the loadings of $\mathrm{Pd}$ on the $\mathrm{ZnO}$ support, indicating a promoted oxidation state of Pd species for low-loading $\mathrm{Pd} / \mathrm{ZnO}$ samples, especially for the $0.01 \%-\mathrm{Pd} / \mathrm{ZnO}$. Our XPS results are also consistent with our XAS findings, which suggests that the

Table 1

EXAFS data fitting results of Pd/ZnO samples with different loadings of Pd reduced at $100^{\circ} \mathrm{C}$.

\begin{tabular}{lcccccc}
\hline Sample & Shell & $N^{\mathrm{a}}$ & $R^{\mathrm{b}}(\AA)$ & $\sigma^{2} \times 10^{2 \mathrm{c}}\left(\AA^{2}\right)$ & $\Delta E_{0} \mathrm{~d}(\mathrm{eV})$ & $\gamma$-factor $(\%)$ \\
\hline Pd foil & Pd-Pd & 12.0 & 2.74 & 5.3 & 1.0 & 0.30 \\
$0.1 \%-P d / Z n 0$ & Pd-0 & 1.5 & 1.99 & 0.61 & -10.3 & 0.24 \\
& Pd-Zn & 0.4 & 2.60 & 0.61 & -10.3 & \\
& Pd-Pd & 4.2 & 2.71 & 0.82 & -10.3 & \\
$1 \%-P d / Z n O$ & Pd-O & 0.9 & 2.00 & 0.61 & -6.9 & 0.38 \\
& Pd-Zn & 1.1 & 2.59 & 0.61 & -6.9 & \\
& Pd-Pd & 5.1 & 2.70 & 0.91 & -6.9 & \\
\hline
\end{tabular}

$\bar{a}$ The coordination number for the absorber-backscatterer pair. ${ }^{\mathrm{b}}$ The average absorber-backscatterer distance. ${ }^{c}$ The Debye-Waller factor. d The inner potential correction. The accuracies of the above parameters were estimated as $N, \pm 20 \% ; R, \pm 1 \% ; \sigma^{2}, \pm 20 \% ; \Delta E_{0}, \pm 20 \%$. The data range used for data fitting in $\kappa$-space and $R$-space are 3.0-12.9 $\AA^{-1}$ and 1.2-2.9 $\AA$, respectively.
$0.01 \%-\mathrm{Pd} / \mathrm{ZnO}$ catalyst behaves as a unique geometric and electronic state for Pd active sites compared with high-loading samples.

\subsection{Catalytic performance}

Finally, the catalytic performances of these three $\mathrm{Pd} / \mathrm{ZnO}$

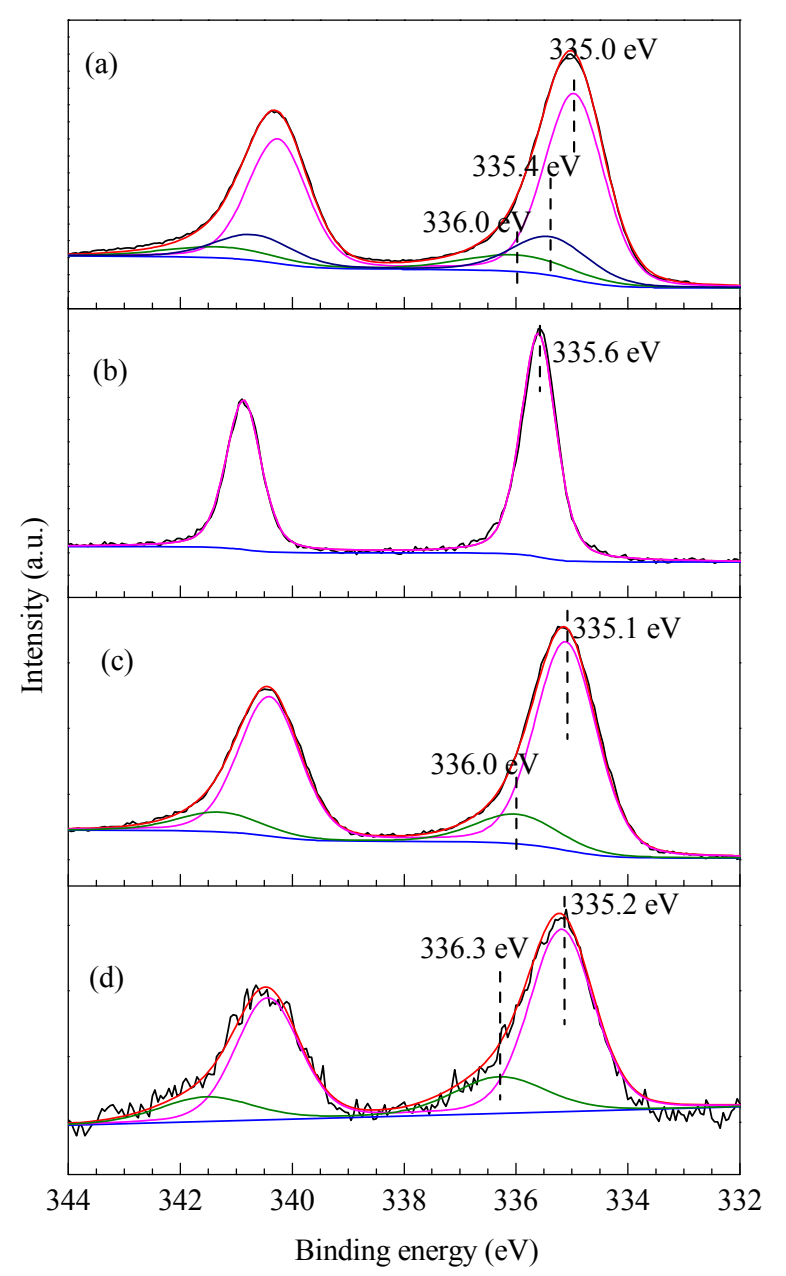

Fig. 5. XPS spectra of Pd $3 d$ peaks for $1 \%$ (a), $0.1 \%$ (c), and $0.01 \%$ (d) $\mathrm{Pd} / \mathrm{ZnO}$ samples reduced at $100{ }^{\circ} \mathrm{C}$, with the $1 \%$-Pd/ZnO sample reduced at $400^{\circ} \mathrm{C}$ for comparison (b). 
Table 2

XPS analysis results of Pd $3 d$ peaks for different samples.

\begin{tabular}{lccccc}
\hline \multirow{2}{*}{ Sample } & & \multicolumn{3}{c}{ Binding energy of Pd $3 d_{5 / 2}(\mathrm{eV})$} & \\
\cline { 3 - 5 } & $T\left({ }^{\circ} \mathrm{C}\right)$ & $\begin{array}{c}\mathrm{Pd}(0) \text { in } \mathrm{Pd} \\
\text { particles }\end{array}$ & $\begin{array}{c}\mathrm{Pd}(0) \text { in } \\
\mathrm{PdZn}\end{array}$ & $\mathrm{Pd}(+)$ & \\
\hline 1\%-Pd/ZnO & 100 & 335.0 & 335.4 & 336.0 & 6.12 \\
1\%-Pd/ZnO & 400 & & 335.6 & & \\
$0.1 \%-\mathrm{Pd} / \mathrm{ZnO}$ & 100 & 335.1 & & 336.0 & 5.23 \\
$0.01 \%-\mathrm{Pd} / \mathrm{ZnO}$ & 100 & 335.2 & & 336.3 & 3.45 \\
\hline
\end{tabular}

T-Reduction temperature.

catalysts were tested in the chemoselective hydrogenation of acetylene. To mimic the industrial process of ethylene purification, the hydrogenation of acetylene was performed in the presence of a large amount of ethylene $\left(2 \mathrm{Vol} \% \mathrm{C}_{2} \mathrm{H}_{2}, 40 \mathrm{Vol} \%\right.$ $\mathrm{C}_{2} \mathrm{H}_{4}$, and $20 \mathrm{Vol} \% \mathrm{H}_{2}$ in the balance with $\mathrm{He}$ ) at isothermal testing at $80{ }^{\circ} \mathrm{C}$. For a more convenient comparison, the conversion of acetylene was controlled at a high conversion (in the range of $80 \%$ to $100 \%$ ) by optimizing the mass of catalysts, because the main challenge in acetylene hydrogenation is the general difficulty in attaining high selectivity toward ethylene owing to the sequential hydrogenation reaction of ethylene at a high conversion of acetylene [7-12].

Fig. 6(a) shows the conversion and selectivity evolution with time on stream for $1 \%$ - $\mathrm{Pd} / \mathrm{ZnO}$ reduced at different temperatures $\left(100\right.$ and $\left.400{ }^{\circ} \mathrm{C}\right)$. The $\mathrm{Pd} / \mathrm{ZnO}$ catalyst reduced at $400{ }^{\circ} \mathrm{C}$ possessed superior activity and selectivity in the semi-hydrogenation of acetylene. A selectivity toward ethylene as high as $\sim 90 \%$ was obtained, and a nearly complete conversion was achieved at $80^{\circ} \mathrm{C}$. As indicated in our previous work [6], this is ascribed to the formation of a PdZn intermetallic alloy with an appropriate spatial arrangement of Pd single sites of Pd-Zn-Pd ensembles at high temperature reduction, which leads to the moderate $\sigma$-bonding of acetylene with two neighboring Pd sites while a weak $\pi$-bonding pattern of ethylene adsorption on the single Pd site, and facilitates the chemisorption of acetylene and promotes the desorption of ethylene from the catalyst surface. This leads to the kinetic favorability of the selective conversion of acetylene to ethylene. In contrast, the $\mathrm{Pd} / \mathrm{ZnO}$ sample reduced at $100{ }^{\circ} \mathrm{C}$ required less catalyst to achieve the complete conversion of acetylene, suggesting it has a high activity; however, it becomes less selective $(\sim 30 \%)$. This can be explained by the Pd nanoparticles becoming predominant on the $\mathrm{ZnO}$ support after low temperature reduction, and the formation of the PdZn intermetallic phase only starting at $100{ }^{\circ} \mathrm{C}$. As a result, it exhibits similar catalytic performance to $\mathrm{Pd}$ nanocatalysts on other supports, such as $\mathrm{SiO}_{2}$ [20], $\mathrm{Al}_{2} \mathrm{O}_{3}$ $[34,35]$ and others [36].

When decreasing the $\mathrm{Pd}$ loading to $0.1 \%$ and reducing at a low temperature $\left(100{ }^{\circ} \mathrm{C}\right)$, both the activity and selectivity greatly increase, with chemoselectivity doubling from $\sim 30 \%$ to $\sim 60 \%$ and a doubling of activity due to the improved Pd dispersion. More interestingly, when decreasing the Pd loading to $0.01 \%$, an exceedingly high chemoselectivity is achieved (> $80 \%$ ), which is comparable to that of $1 \% \mathrm{PdZn}$ intermetallic catalysts, but with a much higher activity (Fig. 6(b)). Therefore, this $0.01 \%-\mathrm{Pd} / \mathrm{ZnO}$ catalyst exhibits different behaviors toward acetylene semi-hydrogenation than do Pd nanocatalysts and $\mathrm{PdZn}$ intermetallic catalysts. It indicates a different origin is involved in the $0.01 \%-\mathrm{Pd} / \mathrm{ZnO}$ catalyst that differs from the nanocatalysts and intermetallic catalysts. According to the characterization results, the single atom $\mathrm{Pd}$ active site plays an important role in its excellent catalytic performance in acetylene semi-hydrogenation. First, this $\mathrm{Pd}_{1} / \mathrm{ZnO} \mathrm{SAC}$ with $\mathrm{Pd}$ single sites will prevent the adsorption of ethylene from $\sigma$-bonding mode to the weak $\pi$-bonding pattern owing to the geometric restraining effect, as a result avoiding the further hydrogenation of ethylene to ethane. In this situation, it behaves similarly to the PdZn intermetallic catalysts, as both of them possess high chemoselectivity toward ethylene in acetylene hydrogenation. Second, the high-valent single Pd active sites can promote electrostatic interactions between the acetylene molecule and the Pd active sites, which facilitates the adsorption and conversion of acetylene. Meanwhile, an induction period of acetylene conversion was observed for the $0.01 \%-\mathrm{Pd} / \mathrm{ZnO}$ catalyst. After $15 \mathrm{~h}$ of testing, the conversion of acetylene remains almost constant with a slight decrease of chemoselectivity, suggesting the relative stability of our $\mathrm{Pd}_{1} / \mathrm{ZnO}$ SACs.
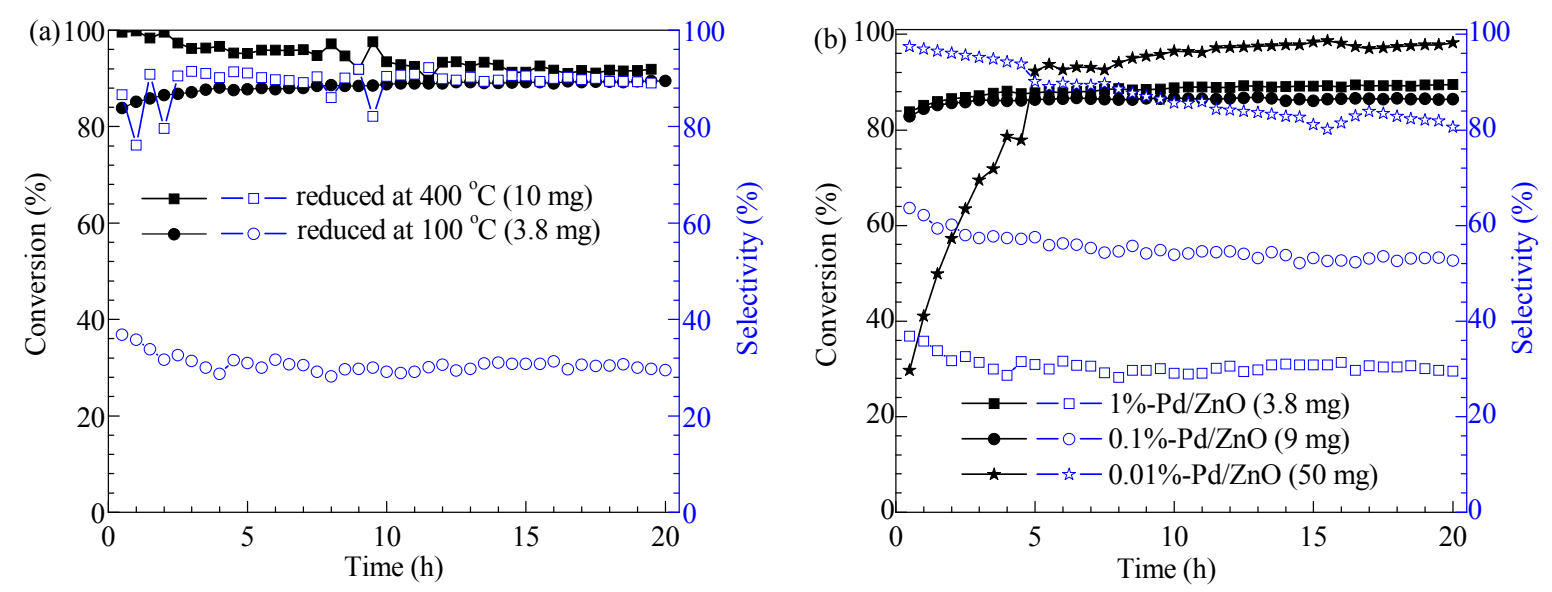

Fig. 6. Conversion and selectivity as a function of time in the selective hydrogenation of acetylene at $80{ }^{\circ} \mathrm{C}$ over $1 \%$-Pd/ZnO reduced at 400 and 100 ${ }^{\circ} \mathrm{C}$ (a) and $1 \%, 0.1 \%, 0.01 \%-\mathrm{Pd} / \mathrm{ZnO}$ reduced at $100{ }^{\circ} \mathrm{C}(\mathrm{b})$. The reaction gas consists of $2 \mathrm{Vol} \% \mathrm{C}_{2} \mathrm{H}_{2}, 20 \mathrm{Vol} \% \mathrm{H}_{2}, 40 \mathrm{Vol} \% \mathrm{C}_{2} \mathrm{H}_{2}$, and $\mathrm{He}$ as balance with a flow rate of $30 \mathrm{~mL} / \mathrm{min}$. 


\section{Conclusions}

In order to obtain differently sized Pd species, notably single atom $\mathrm{Pd}$ sites, different $\mathrm{Pd} / \mathrm{ZnO}$ catalysts were obtained by lowering the content of $\mathrm{Pd}$ on $\mathrm{ZnO}$ supports. Our characterization results indicate that the $\mathrm{Pd}$ nanoparticle size decreased with the Pd loading from $1 \%$ to $0.1 \%$, and became single-atom distributed $\mathrm{Pd}$ sites for the $0.01 \%-\mathrm{Pd} / \mathrm{ZnO}$ catalyst. Unexpectedly, this $0.01 \%-\mathrm{Pd}_{1} / \mathrm{ZnO}$ SAC exhibited excellent catalytic performance in the chemoselective hydrogenation of acetylene, with a comparable chemoselectivity and an improved activity compared with those of our previously reported PdZn intermetallic catalysts. The selectivity to ethylene is $>80 \%$ at nearly $100 \%$ conversion and a space velocity of $36000 \mathrm{~mL} \cdot \mathrm{g}^{-1} \cdot \mathrm{h}^{-1}$ at $80^{\circ} \mathrm{C}$. This unusual behavior of the $\mathrm{Pd}_{1} / \mathrm{ZnO}$ SAC in acetylene semi-hydrogenation was ascribed to its high-valent single Pd active sites, which could promote electrostatic interactions with acetylene but restrain undesired ethylene hydrogenation by spatial restriction on $\sigma$-chemical bonding toward ethylene. Such SACs provides an excellent chance to design new catalysts to achieve unique active sites and optimize the activity and selectivity of heterogeneous catalysis. Toward these goals, further studies on SACs for other chemoselective reactions are ongoing in our group.

\section{References}

[1] G. A. Somorjai, J. Y. Park, Angew. Chem. Int. Ed., 2008, 47, 9212-9228.

[2] H. S. Wei, X. Wei, X. F. Yang, G. Z. Yin, A. Q. Wang, X. Y. Liu, Y. Q. Huang, T. Zhang, Chin. J. Catal., 2015, 36, 160-167.

[3] J. Gao, H. B. Zhao, X. F. Yang, B. E. Koel, S. G. Podkolzin, Angew.
Chem. Int. Ed., 2014, 53, 3641-3644.

[4] S. R. Zhang, L. Nguyen, J. X. Liang, J. J. Shan, J. Y Liu, A. I. Frenkel, A. Patlolla, W. X. Huang, J. Li, F. Tao, Nat. Commun., 2015, 6, 7938.

[5] J. Osswald, R. Giedigkeit, R. E. Jentoft, M. Armbrüster, F. Girgsdies, K. Kovnir, T. Ressler, Y. Grin, R. Schlögl, J. Catal., 2008, 258, 210-218.

[6] H. R. Zhou, X. F. Yang, L. Li, X. Y. Liu, Y. Q. Huang, X. L. Pan, A. Q. Wang, J. Li, T. Zhang, ACS Catal., 2016, 6, 1054-1061.

[7] A. Borodziński, G. C. Bond, Catal. Rev.-Sci. Eng., 2006, 48, 91-144.

[8] A. Borodziński, G. C. Bond, Catal. Rev.-Sci. Eng., 2008, 50, 379-469.

[9] S. A. Nikolaev, L. N. Zanaveskin, V. V. Smirnov, V. A. Averyanov, K. L. Zanaveskin, Russ. Chem. Rev., 2009, 78, 231-247.

[10] M. Crespo-Quesada, F. Cárdenas-Lizana, A. L. Dessimoz, L. Kiwi-Minsker, ACS Catal., 2012, 2, 1773-1786

[11] M. Armbrüster, M. Behrens, F. Cinquini, K. Föttinger, Y. Grin, A. Haghofer, B. Klötzer, A. Knop-Gericke, H. Lorenz, A. Ota, S. Penner, J. Prinz, C. Rameshan, Z. Révay, D. Rosenthal, G. Rupprechter, P. Sautet, R. Schlögl, L. Shao, L. Szentmiklósi, D. Teschner, D. Torres, R. Wagner, R. Widmer, G. Wowsnick, ChemCatChem, 2012, 4, 1048-1063.

[12] N. López, C. Vargas-Fuentes, Chem. Commun., 2012, 48, 1379-1391.

[13] J. Lin, A. Q. Wang, B. T. Qiao, X. Y. Liu, X. F. Yang, X. D. Wang, J. X. Liang, J. Li, J. Y. Liu, T. Zhang, J. Am. Chem. Soc., 2013, 135, 15314-15317.

[14] B. T. Qiao, A. Q. Wang, X. F. Yang, L. F. Allard, Z. Jiang, Y. T. Cui, J. Y. Liu, J. Li, T. Zhang, Nat. Chem., 2011, 3, 634-641.

[15] B. T. Qiao, J. Lin, A. Q. Wang, Y. Chen, T. Zhang, J. Y. Liu, Chin. J. Catal., 2015, 36, 1505-1511.

[16] X. F. Yang, A. Q. Wang, B. T. Qiao, J. Li, J. Y. Liu, T. Zhang, Acc. Chem. Res., 2013, 46, 1740-1748.

[17] H. S. Wei, X. Y. Liu, A. Q. Wang, L. L. Zhang, B. T. Qiao, X. F. Yang, Y. Q. Huang, S. Miao, J. Y. Liu, T. Zhang, Nat. Commun., 2014, 5, 5634.

[18] Y. Boudeville, F. Figueras, M. Forissier, J. L. Portefaix, J. C. Vedrine, J. Catal., 1979, 58, 52-60.

\section{Graphical Abstract}

Chin. J. Catal., 2016, 37: 692-699 doi: 10.1016/S1872-2067(15)61090-7

\section{Pd/ZnO catalysts with different origins for high chemoselectivity in acetylene semi-hydrogenation}

Huiran Zhou, Xiaofeng Yang*, Aiqin Wang*, Shu Miao, Xiaoyan Liu, Xiaoli Pan, Yang Su, Lin Li, Yuan Tan, Tao Zhang Dalian Institute of Chemical Physics, Chinese Academy of Sciences; University of Chinese Academy of Sciences
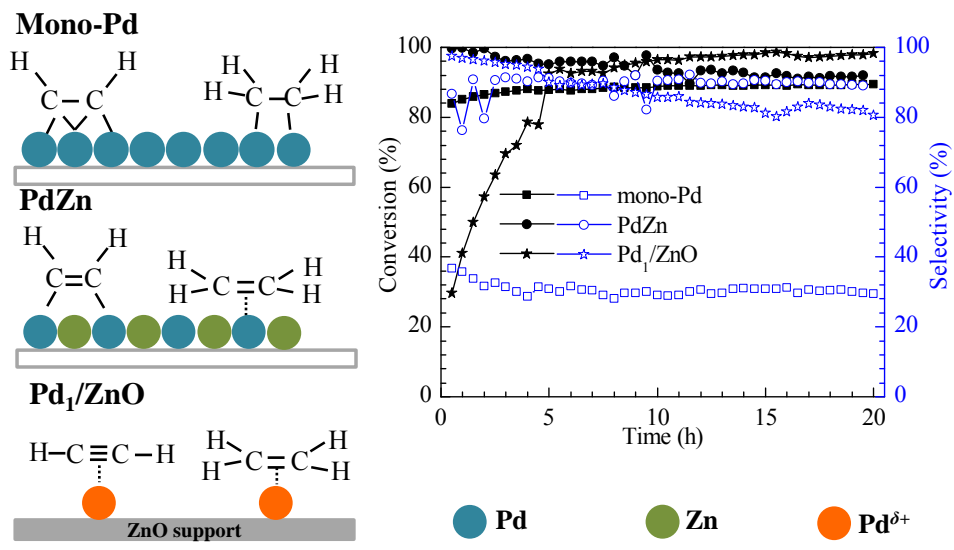

A Pd-based single atom catalyst was achieved on a $\mathrm{ZnO}$ support, which exhibits excellent catalytic performances with a comparably high chemoselectivity but a different origin to that of PdZn catalysts in acetylene semi-hydrogenation. 
[19] X. Y. Liu, C. Y. Mou, S. Lee, Y. Li, J. Secrest, B. W. L. Jang, J. Catal., 2012, 285, 152-159.

[20] G. X. Pei, X. Y. Liu, A. Q. Wang, A. F. Lee, M. A. Isaacs, L. Li, X. L. Pan, X. F. Yang, X. D. Wang, Z. J. Tai, K. Wilson, T. Zhang, ACS Catal., 2015, 5, 3717-3725.

[21] C. T. Hong, C. T. Yeh, F. H. Yu, Appl. Catal., 1989, 48, 385-396.

[22] M. Armbrüster, M. Behrens, K. Föttinger, M. Friedrich, E. Gaudry, S. K. Matam, H. R. Sharma, Catal. Rev.-Sci. Eng., 2013, 55, 289-367.

[23] M. L. Cubeiro, J. L. G. Fierro, J. Catal., 1998, 179, 150-162.

[24] Y. H. Chin, R. Dagle, J. L. Hu, A. C. Dohnalkova, Y. Wang, Catal. Today, 2002, 77, 79-88.

[25] Y. Uemura, Y. Inada, Y. Niwa, M. Kimura, K. K. Bando, A. Yagishita, Y. Iwasawa, M. Nomura, Phys. Chem. Chem. Phys., 2012, 14, 2152-2158.

[26] M. Crespo-Quesada, S. Yoon, M. S. Jin, Y. N. Xia, A. Weidenkaff, L. Kiwi-Minsker, ChemCatChem, 2014, 6, 767-771.

[27] I. S. Mashkovsky, G. N. Baeva, A. Y. Stakheev, M. N. Vargaftik, N. Y. Kozitsyna, I. I. Moiseev, Mendeleev Commun., 2014, 24, 355-357.

[28] M. W. Tew, H. Emerich, J. A. van Bokhoven, J. Phys. Chem. C, 2011,
115, 8457-8465.

[29] A. I. Frenkel, C. W. Hills, R. G. Nuzzo, J. Phys. Chem. B, 2001, 105, 12689-12703.

[30] A. Sarkany, Z. Zsoldos, B. Furlong, J. W. Hightower, L. Guczi, J. Catal., 1993, 141, 566-582.

[31] L. N. Protasova, E. V. Rebrov, K. L. Choy, S. Y. Pung, V. Engels, M. Cabaj, A. E. H. Wheatley, J. C. Schouten, Catal. Sci. Technol., 2011, 1, 768-777.

[32] C. Rameshan, W. Stadlmayr, C. Weilach, S. Penner, H. Lorenz, M. Hävecker, R. Blume, T. Rocha, D. Teschner, A. Knop-Gericke, R. Schlögl, N. Memmel, D. Zemlyanov, G. Rupprechter, B. Klötzer, Angew. Chem. Int. Ed., 2010, 49, 3224-3227.

[33] N. Iwasa, S. Masuda, N. Ogawa, N. Takezawa, Appl. Catal. A, 1995, 125, 145-157.

[34] N. Wongwaranon, O. Mekasuwandumrong, P. Praserthdam, J. Panpranot, Catal. Today, 2008, 131, 553-558.

[35] Q. W. Zhang, J. Li, X. X. Liu, Q. M. Zhu, Appl. Catal. A, 2000, 197, 221-228.

[36] Y. N. Li, B. W. L. Jang, Appl. Catal. A, 2011, 392, 173-179.

\title{
$\mathrm{Pd} / \mathrm{ZnO}$ 在乙炔选择加氢反应中的不同催化机制研究
}

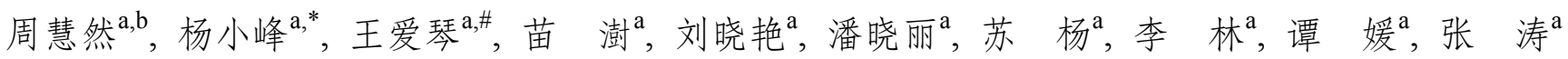 \\ ${ }^{\mathrm{a}}$ 中国科学院大连化学物理研究所催化基础国家重点实验室，能源材料化学协同创新中心，辽宁大连116023 \\ b中国科学院大学, 北京 100049
}

摘要: 化学选择性是评价催化剂性能最重要的参数之一, 它直接决定了产物的经济价值及后续的分离成本. 传统的负载型 金属催化剂由于其金属粒径分布不均, 且不同原子数组成的粒子通常具有特征产物选择性, 从而限制化学选择性的提高; 另一方面, 对于金属多原子活性中心, 反应物在催化剂表面可以存在多种吸附构型进而衍化为不同产物, 产物可控性差. 因此, 获得金属尺寸均一, 且具有原子分散的活性中心, 即单原子催化剂, 成为官能团多相催化转化高选择性的迫切需求.

本课题组通过 $400{ }^{\circ} \mathrm{C}$ 还原 $1 \%-\mathrm{Pd} / \mathrm{ZnO}$ 得到 $\mathrm{PdZn}$ 金属间化合物, 依据其规律排布的 $\mathrm{Pd}-\mathrm{Zn}-\mathrm{Pd}$ 单元获得 $\mathrm{Pd}$ 基单原子 催化剂. 该催化剂在乙烯化工中少量乙炔的加氢转化反应中获得令人欣喜的催化性能——兼具有乙炔的高转化率和乙烯 的高选择性. 结合微量吸附量热、理论计算等表征, Pd 活性中心在 PdZn 金属间化合物中的特殊空间排布是其优异催化性 能的根源, 即乙炔以较强的 $\sigma$ 键吸附在两个相邻的单 Pd 金属中心, 易吸附活化加氢生成乙烯, 而乙烯则吸附于单 $P d$ 金属中 心, 较弱的 $\pi$ 键形式吸附有利于其脱附避免过渡加氢. 基于前期研究, 构筑具有均一单金属中心的负载型单原子催化剂是 获得高选择性的另一有效方法, 且较之于 PdZn 金属间化合物催化剂, 该类单原子催化剂兼具有原子利用率最大化的优点.

本文采用等体积浸渍法制备 $\mathrm{Pd} / \mathrm{ZnO}$ 催化剂, 通过降低 $\mathrm{Pd}$ 金属含量 $(1 \mathrm{wt} \% \rightarrow 0.1 \mathrm{wt} \% \rightarrow 0.01 \mathrm{wt} \%)$ 并在较低的温度 下 $\left(100{ }^{\circ} \mathrm{C}\right)$ 还原 $\left(\mathrm{H}_{2}-\mathrm{TPR}\right.$ 表明高温还原形成 $\mathrm{PdZn}$ 金属间化合物型合金) 得到负载型单原子催化剂 $\left(\mathrm{Pd}_{1} / \mathrm{ZnO} \mathrm{SAC}\right)$. 高分 辨电镜结果表明, 当 $\mathrm{Pd}$ 负载量由 $1 \%$ 降至 $0.1 \%$, 金属纳米颗粒的粒径尺寸显著降低, 而在 $0.01 \%-\mathrm{Pd} / \mathrm{ZnO}$ 催化剂表面, $\mathrm{Pd}$ 活性中心则以单原子状态分散于载体 $\mathrm{ZnO}$ 表面. X-射线吸收光谱及电子能谱表明, 随着负载量的降低, Pd 活性物种具有 更高的正电性. 该催化剂在乙炔选择性加氢反应中表现出更加优越的催化性能, 具有与 PdZn 催化剂相当的高选择性, 而 更优的比活性. 这归结于 $\mathrm{Pd}_{1} / \mathrm{ZnO}$ 单原子催化剂的 $\mathrm{Pd}^{\delta+}$ 单原子活性中心有助于其与乙炔的静电相互作用并吸附活化加氢 生成乙烯, 并促使乙烯以较弱的 $\pi$ 键吸附, 从而易于从催化剂表面脱附获得高选择性.

关键词: 单原子催化剂; 乙炔加氢; 化学选择性; 钯; 氧化锌

收稿日期: 2016-02-26. 接受日期: 2016-03-28. 出版日期: 2016-05-05.

*通讯联系人. 电话: (0411)84379416; 传真: (0411)84685940; 电子信箱: yangxf2003@dicp.ac.cn

\#通讯联系人. 电话: (0411)84379348; 传真: (0411)84685940; 电子信箱: aqwang@dicp.ac.cn

基金来源：国家自然科学基金 (21573232).

本文的英文电子版由Elsevier出版社在ScienceDirect上出版(http://www.sciencedirect.com/science/journal/18722067). 